\title{
THE NORMAL CEREBRO-SPINAL FLUID IN CHILDREN.
}

\author{
BY
}

\author{
DONALD STEWAR'T, M.D.
}

(From the Royal Hospital for Sick Children, and the Laboratory of the Royal College of Physicians, Edinburgh.)

For comparison with the findings in disease, it is necessary to determine the characteristics of the cerebro-spinal fluid in healthy infants and children. Comparatively little work has been done on this subject. In the latest work on the cerebro-spinal fluid, The Human Cerebro-spinal Fluid, published by the Association for Research in Nervous and Mental Diseases, New York, McLean and McIntosh ${ }^{1}$ introduce their chapter on the cerebro-spinal fluid in infants and young children, with a brief account of the normal fluid. They do not state the number of cases examined, but their conclusions are no doubt based on observations sufficiently wide to ensure a reasonable degree of accuracy. Wilcox and Lyttle ${ }^{2}$, in a paper on the chemical composition of the spinal fluid in childhood, give their results in a series of twenty-three normal cases.

In the present investigation, fifty cases were examined, a number probably large enough to enable us to form an accurate conception of the condition of the fluid in health. As will be seen from Table 1 , the children have been divided into eight age groups: the youngest child examined was seven days old, and the oldest twelve years. It will be seen also, that twenty-eight of the fifty cases were children under two years of age.

TABLE I.

AGE GROLPS OF FIFTY CHILDREN EXAMINEI).

\begin{tabular}{|c|c|c|c|c|}
\hline Age group. & \multicolumn{3}{|c|}{ Age limits. } & No. of cases. \\
\hline 1 & 7 days & to & 3 months & 10 \\
\hline 2 & 3 months & to & 1 year & 10 \\
\hline 3 & 1 year & to & 2 years & 8 \\
\hline 4 & 2 years & to & $3 \quad$, & 5 \\
\hline i) & $3 \quad$, & to & ij & $\tilde{5}$ \\
\hline 6 & 5 & to & , & 4 \\
\hline 7 & 7 & to & 10 & 4 \\
\hline si & 10 & to & 12 & + \\
\hline
\end{tabular}

The children whose cerebro-spinal fluid was withdrawn for this study were all in a healthy condition. Each was examined carefully before the punctures were performed.

A comparative study of the normal fluid obtained from different sites was also undertaken. In each of the fifty cases the lumbar fluid was examined; in thirty-five the cistern fluid, and in nine the ventricular fluid was examined. 
The work described in this paper does not claim to represent a complete investigation of the normal cerebro-spinal fluid in children. It is rather a study of the commoner aspects of the subject. But it is just those commoner aspects that are of special importance to the clinician, and it is hoped accordingly that the results here shown may serve a useful purpose from the view-point of clinical diagnosis.

The following are the points included within the investigation :-1. Pressure studies. 2. Cytology. 3. Protein Content. 4. Sugar Content. 5. Chloride Content.

\section{Pressure Studies.}

The fluid pressure was estimated manometrically in ten children. A simple aneroid manometer, such as described by Levinson ${ }^{3}$, was used for these observations. The measurements were taken at lumbar puncture, immediately after the insertion of the needle, with the child in the sitting position. Table II gives the results in these cases.

TABLE II.

PRESSURE OF CEREBRO-SPINAL FLUID AT LUMBAR PUNCTURE.

\begin{tabular}{|c|c|c|c|}
\hline & Age. & Pressure. & Observations. \\
\hline 1 & 10 weeks & $35 \mathrm{~mm}$. & Cried hard all the time. \\
\hline 2 & 3 months & 75, & Absolutely still. \\
\hline 3 & $9 \quad$, & 240, & $\begin{array}{l}\text { Spasmodic crying ; pressure rose and fell } 110 \mathrm{~mm} \text {., with } \\
\text { crying fits. }\end{array}$ \\
\hline 4 & 10, & 110, & $\begin{array}{l}\text { - Very restless; struggled hard. Reading varied } 60 \text { - } \\
100 \mathrm{~mm} .\end{array}$ \\
\hline$\tilde{5}$ & 4 years & 94 & Respirations $30-40$ at times; otherwise nil to note. \\
\hline 6 & $6 \frac{1}{2} \quad$, & 300, & $\begin{array}{l}\text { Continual movement, although held by two assistants. } \\
\text { Variation of } 30-100 \mathrm{~mm} \text {. }\end{array}$ \\
\hline 7 & J0 & 50 & Absolutely still. No variation in reading. \\
\hline 8 & 11 & $160 \quad,$. & Absolutely still. No variation in reading. \\
\hline 9 & 11 & 200, & Slight cough ; reading varied $30-50 \mathrm{~mm}$. \\
\hline 10 & 11 & 190 & $\begin{array}{l}\text { Struggled hard ; cried and coughed. Reading varied } \\
50-60 \text { mm. even with slight movement; } 100- \\
120 \text { with crying and coughing. }\end{array}$ \\
\hline
\end{tabular}

From the differences disclosed in these readings (Table II), it becomes apparent that in normal children it is difficult to obtain accurate manometric results. There are many factors by which the pressure is influenced. The position of the patient, to begin with, is a matter of importance. Ayer ${ }^{4}$ states that " in the sitting position the lumbar pressure is approximately doubled, while at the cisterna magna the pressure is below zero, i.e., a negative pressure ; similarly the ventricular pressure is negative, a fact which can be readily checked by palpation of the normal infant's fontanelle." Infants and young children commonly resent lumbar puncture. They sometimes cry, cough, sneeze, hold their breaths, or even struggle and move their bodies. All these factors materially affect the pressure, any one of them being sufficient to send it up $100 \mathrm{~mm}$. or more. It may therefore be concluded that in infants and in young children manometric estimation of the fluid pressure is unreliable, and accordingly of no diagnostic value to the pædiatrician. 
TABLE III.

CELL-COUNTS IN DIFFERENT AGE GROUPS.

\begin{tabular}{|c|c|c|c|c|c|}
\hline \multirow{2}{*}{$\begin{array}{l}\text { Age } \\
\text { group. }\end{array}$} & \multirow{2}{*}{$\begin{array}{l}\text { Case } \\
\text { No. }\end{array}$} & \multirow{2}{*}{ Age. } & \multicolumn{3}{|c|}{ Total cells per cubic $\mathrm{mm}$. } \\
\hline & & & Lumbar. & Cistern. & Ventricle. \\
\hline I & $\begin{array}{r}1 \\
2 \\
3 \\
4 \\
5 \\
6 \\
7 \\
8 \\
9 \\
10\end{array}$ & 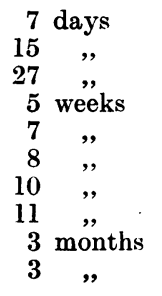 & $\begin{array}{l}34 \\
28 \\
18 \\
20 \\
24 \\
18 \\
16 \\
23 \\
19 \\
27\end{array}$ & $\begin{array}{l}\frac{27}{12} \\
\frac{22}{18} \\
28 \\
15\end{array}$ & $\begin{array}{l}\overline{-} \\
\frac{0}{1} \\
\frac{1}{0} \\
0 \\
\frac{2}{-}\end{array}$ \\
\hline II & $\begin{array}{l}11 \\
12 \\
13 \\
14 \\
15 \\
16 \\
17 \\
18 \\
19 \\
20\end{array}$ & $\begin{aligned} 4 & \text { months } \\
4 & , \\
6 & , \\
6 & , \\
7 & , \\
9 & , \\
9 & , \\
10 & , \\
12 & , \\
12 & \end{aligned}$ & $\begin{array}{r}18 \\
10 \\
15 \\
9 \\
21 \\
8 \\
17 \\
15 \\
24 \\
11\end{array}$ & $\begin{array}{r}16 \\
14 \\
14 \\
20 \\
\frac{6}{12} \\
20 \\
-\end{array}$ & $\begin{array}{l}-0 \\
0 \\
0 \\
0 \\
- \\
- \\
-\end{array}$ \\
\hline III & $\begin{array}{l}21 \\
22 \\
23 \\
24 \\
25 \\
26 \\
27 \\
28\end{array}$ & $\begin{array}{l}13 \text { months } \\
15 \text { ", } \\
15 \text { ", } \\
19 \text { ", } \\
19 \text { ", } \\
21 \text { years } \\
2 \text { " } \\
\end{array}$ & $\begin{array}{r}14 \\
12 \\
8 \\
17 \\
16 \\
20 \\
15 \\
10\end{array}$ & $\begin{array}{r}12 \\
10 \\
6 \\
14 \\
14 \\
11\end{array}$ & $\begin{array}{l}- \\
= \\
= \\
=\end{array}$ \\
\hline IV & $\begin{array}{l}29 \\
30 \\
31 \\
32 \\
33 \\
\end{array}$ & $\begin{array}{lc}2 \frac{2}{12} & \text { years } \\
2_{\frac{7}{12}}^{7} & \Rightarrow \\
3 \frac{9}{12} & \Rightarrow \\
3 & , \\
3 & \text { " }\end{array}$ & $\begin{array}{r}9 \\
15 \\
12 \\
8 \\
20\end{array}$ & $\begin{array}{r}8 \\
8 \\
12 \\
14\end{array}$ & $\begin{array}{l}- \\
- \\
-\end{array}$ \\
\hline $\mathrm{V}$ & $\begin{array}{l}\mathbf{3 4} \\
\mathbf{3 5} \\
\mathbf{3 6} \\
\mathbf{3 7} \\
\mathbf{3 8}\end{array}$ & 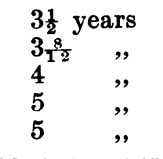 & $\begin{array}{r}15 \\
17 \\
14 \\
10 \\
4\end{array}$ & $\begin{array}{l}10 \\
10 \\
8 \\
3\end{array}$ & $\frac{-}{-}$ \\
\hline VI & $\begin{array}{l}39 \\
40 \\
41 \\
42\end{array}$ & $\begin{array}{lc}5 \frac{1}{2} & \text { years } \\
6 & , \\
7 & , \\
7 & ,\end{array}$ & $\begin{array}{r}11 \\
8 \\
12 \\
9\end{array}$ & $\begin{array}{r}-7 \\
11 \\
9\end{array}$ & E \\
\hline VII & $\begin{array}{l}43 \\
44 \\
45 \\
46\end{array}$ & $\begin{array}{rr}8 & \text { years } \\
8 & , \\
8 & , \\
10 & , \\
\end{array}$ & $\begin{array}{r}8 \\
6 \\
10 \\
5\end{array}$ & $\begin{array}{r}5 \\
6 \\
- \\
-\end{array}$ & $\frac{-}{-}$ \\
\hline VIII & $\begin{array}{l}47 \\
49 \\
48 \\
50\end{array}$ & $\begin{array}{l}11 \text { years } \\
11 \frac{1}{2} \quad " \\
12 \quad, \\
12 \quad,\end{array}$ & $\begin{array}{l}8 \\
4 \\
3 \\
7\end{array}$ & $\begin{array}{l}6 \\
6 \\
3 \\
-\end{array}$ & E \\
\hline
\end{tabular}


Even approximate estimation of the pressure is a matter of great difficulty in children. If the manometer can give results which are almost impossible to interpret, practically nothing can be estimated from the rate of flow of fluid through the needle. In a child, normal in every way, the fluid may spurt out two or three feet at lumbar puncture; while again, in cases of tuberculous meningitis, with definite signs of increased intracranial pressure, and with no block in the spinal-subarachnoid space, the fluid in many cases may not spurt out half as far. The use of the phrase, "the fluid was under pressure," which is based entirely on the rate of flow through the needle, is therefore no indication of the fluid tension, and is apt in many cases to be misleading. Estimation of the pressure by counting the drops per unit of time cannot be too severely condemned. Ayer ${ }^{4}$ found that often where fluid came slowly from the needle, the manometric reading rose to pathological heights.

In order to obtain an approximate estimate of the pressure in the fluid of children, various rules have to be observed. Lumbar puncture should be done in all cases with the patient in the same position, and there must be complete elimination, as far as possible, of the disturbing factors already mentioned. How far this is possible may only be ascertained after long experience. In our experience in infants and young children, it is, to all intents and purposes, impossible.

\section{Cytology.}

In estimating the cell count, a Fuchs-Rosenthal ${ }^{5}$ counting-chamber was employed. When red and white blood cells were present, and even when an estimate was approximately arrived at, the cell count was not accurate. Efforts were made in every case to see that there was no blood contamination in the fluids examined.

Table III shows the total cell count in the various age groups.

In Table IV, the lumbar and cistern fluids are compared in the different age groups, as regards (1) the limits of variation in the number of cells per cubic millimetre, and (2) the average number of cells per cubic millimetre.

TABLE IV.

COMPARISON OF CYTOLOGY OF LUMBAR AND CISTERN FLUIDS.

\begin{tabular}{|c|c|c|c|c|}
\hline \multirow{2}{*}{$\begin{array}{l}\text { Age } \\
\text { group. }\end{array}$} & \multicolumn{2}{|c|}{ Lumbar fluid. } & \multicolumn{2}{|c|}{ Cistern fluid. } \\
\hline & Variation. & Average. & Variation. & Average. \\
\hline 1 & $16-34$ & 23 & $12-27$ & 20 \\
\hline 2 & $8-24$ & 15 & $6-20$ & 14 \\
\hline 3 & $8-20$ & 14 & $6-14$ & 11 \\
\hline 4 & $8-20$ & 12 & $8-14$ & 10 \\
\hline 5 & $4-17$ & 12 & $3-15$ & 10 \\
\hline 6 & $8-12$ & 10 & $6-11$ & 8 \\
\hline 7 & $5-10$ & 7 & $5-16$ & 6 \\
\hline 8 & $3-8$ & 6 & $2-6$ & 4 \\
\hline
\end{tabular}

The ventricular fluid was examined in nine children, aged twenty-seven days to nine months. One case showed two small lymphocytes, another showed one. The other ventricular fluids contained no cells, 
Differential Cell Count.-Small lymphocytes constituted the greater part of every cell count, being from 94 to 100 per cent. of the total count. Frequently large lymphocytes were found, but they did not in any case constitute more than 6 per cent. In no case were polymorphonuclear cells present.

Summary.-1. The total cell count varied in the lumbar fluid from 34 cells per c. $\mathrm{mm}$. in an infant of seven days, to 3 per c.mm. in a child of twelve years; and in the cistern fluid from 28 per c.mm. in a child of eleven weeks, to 3 per c.mm. in two cases aged five and twelve years respectively.

2 . In five cases the cell count in the cistern fluid was greater, in three equal to, and in the remaining twenty-seven less than, the count in the lumbar fluid. The difference was never more than seven, and in the great majority of cases was from one to four.

3. The ventricular fluid in two cases showed 1 and 2 cells per c.mm. respectively. The other fluids, seven in number, contained no cells.

4. The differential count showed that all the cells were mononuclear. Small lymphocytes varied from 94 to 100 per cent., and large lymphocytes up to 6 per cent. of the total count.

Conclusions.-1. The cell count varies approximately with the age of the child, the highest counts being found in the youngest children.

2. In the great majority of cases the cell count is slightly greater in the lumbar fluid than in the cistern fluid.

3. The normal ventricular fluid in infants contains no cells as a rule, but occasionally one or two may be present.

4. In children all the cells are mononuclear, small and large lymphocytes being in the proportion of about $20: 1$.

\section{Protein Content.}

The value of careful quantitative estimation of protein is obvious. In many diseases of the nervous system the appearance of abnormal amounts of protein in the spinal fluid is one of the earliest abnormal signs. Thus it is essential to know the normal amounts, and, if possible, the amounts to be expected in different pathological conditions. An accurate method of quantitative estimation is therefore necessary.

Method of Estimation.-During the past number of years many methods of estimating the protein content of the cerebro-spinal fluid have been used.

Picric acid methods, either by the ordinary urine albuminometer or with Aufrecht's albuminometer, are at the best only approximate estimations, and the want of a more accurate method was felt for a long time. For some years the French, who were pioneers in cerebrospinal pathology, have expressed their protein determinations in figures. They used for the most part the Mestrezat ${ }^{6}$ trichloracetic acid method, and more recently that advocated by Ravaut and Boyer ${ }^{7}$, in which silver chloride is used as a standard.

In 1920, Denis and Ayer ${ }^{8}$ described a method for the quantitative determination of protein in the fluid, and this method has been used by them and other workers in America with satisfactory results. They use protein as a standard, and in the estimation an unknown protein precipitate is compared with a known protein precipitate. 
TABLE V.

PROTEIN CONTENT IN CEREBRO-SPINAL FLUID.

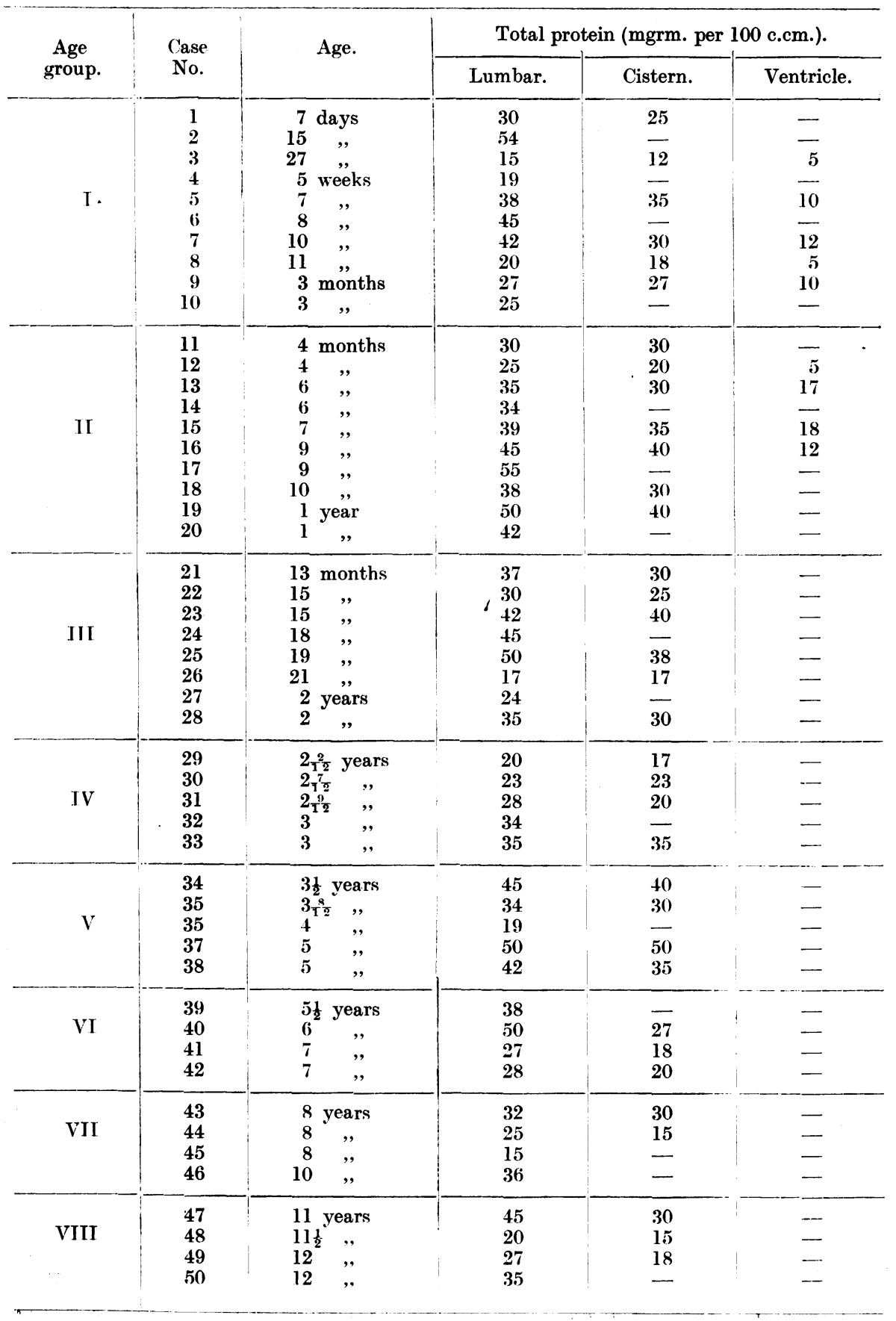


The method of Denis and Ayer has two important advantages over the other methods in use, namely, the small amount of fluid necessary for the test, and the short time taken to complete the test. Usually a number of examinations have to be undertaken on a small amount of fluid, and so the advantages of a test which necessitates the use of only $0.6 \mathrm{c.cm}$., or at most 1 c.cm., are obvious. The protein content may be estimated in one fluid in about ten minutes, and twenty fluids can be examined in less than half an hour.

In the present series of tests the protein was determined by the method of Denis and Ayer on the first $3 \mathrm{c.cm}$. of fluid, assuming that the amount of fluid withdrawn might modify the protein content.

Table $\mathrm{V}$ shows the readings from lumbar, cistern and ventricular fluids, in the various age groups in mgrm. per $100 \mathrm{cc}$.

It will be seen from the above table that there is no variation of the total protein with the age of the patient, such as was noted in the cell count.

From Table VI it may be seen that the readings in the lumbar fluid vary from 15 to $55 \mathrm{mgrm}$. per $100 \mathrm{c.cm}$., with an average of $33 \mathrm{mgrm}$. In the cistern fluid, the variation was from 12 to 50, the average being $28 \mathrm{mgrm}$. In nine ventricular fluids, the readings varjed from 5) to 18 , with an average of $11 \mathrm{mgrm}$. per $100 \mathrm{c.cm}$.

TABLE VI.

AVERAGE IN PROTEIN CONTENT.

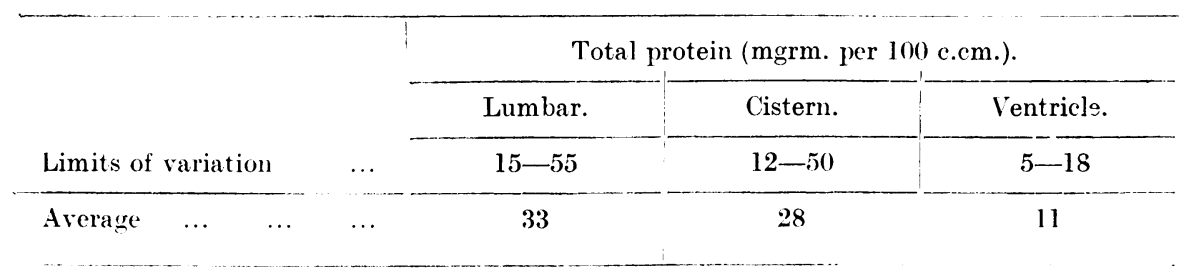

Ayer and Foster 9 , using the method of Denis and Ayer, found that the amount of protein normally present in the lumbar fluid in patients of all ages, varies between 15 and 45 mgrm. per $100 \mathrm{c.cm}$. Mestrezat ${ }^{6}$ considers 15 to $30 \mathrm{mgrm}$. as normal, and the error in his diaphanometric method is stated by Greenfield and Carmichael ${ }^{10}$ to be less than 20 per cent. Eskuchen ${ }^{11}$ gives 20 to $30 \mathrm{mgrm}$. as normal. Young and Bennett ${ }^{12}$, using a method of their own with 95 per cent. ethyl alcohol as the precipitating agent, find that normal fluids contain 25 to 75 mgrm. per 100 c.cm.

Fremont-Smith and Ayer ${ }^{13}$ state that in the cisterna magna the norma? range is from 10 to $25 \mathrm{mgrm}$., and in the ventricles from $5 \mathrm{mgrm}$. or less, to $15 \mathrm{mgrm}$. In one case of a child aged five years, normal in every respect, the presant writer found $50 \mathrm{mgrm}$. in the cistern fluid: but his highest reading in the ventricular fluid was $18 \mathrm{mgrm}$. per $100 \mathrm{c.cm}$.

It is interesting to note that, in the main, our results resemble those of Ayer and Foster ${ }^{9}$, who originally used this method. In children, we have found higher figures in cistern fluids than they did in patients of all ages, and in many cases not so much difference between the lumbar and cisternal content. 
Summary. The total protein in the lumbar region varied from 15 to 55 mgrm. per 100 c.cm., with an average of 33 ; in the cisterna magna from 12 to 50 , average 28 ; and in the ventricle from 5 to 18 , giving an average of $11 \mathrm{mgrm}$. per $100 \mathrm{c.cm}$.

Conclusions. 1. The protein content in the lumbar fluid does not vary with the age of the child.

2. The protein content in the lumbar fluid of children is similar to that in the lumbar fluid of adults.

3. In children there is less difference than in adults between the total protein in the lumbar and cistern fluids.

4. The protein content in the ventricular fluid of infants is similar to that in the ventricular fluid of adults.

\section{Sugar Content.}

The sugar content of the normal cerebro-spinal fluid was estimated in thirty cases. In each case the blood sugar was also estimated, Maclean's't method being used for both.

Relation of the spinal fluid sugar to the blood sugar. The relation between the spinal fluid sugar and the blood sugar has long been a subject of controversy, but most workers now agree that, normally, the sugar content of the

TABLE VII.

COMPARISON OF SUGAR IN CEREBRO-SPINAL FLUID AND BLOOI).

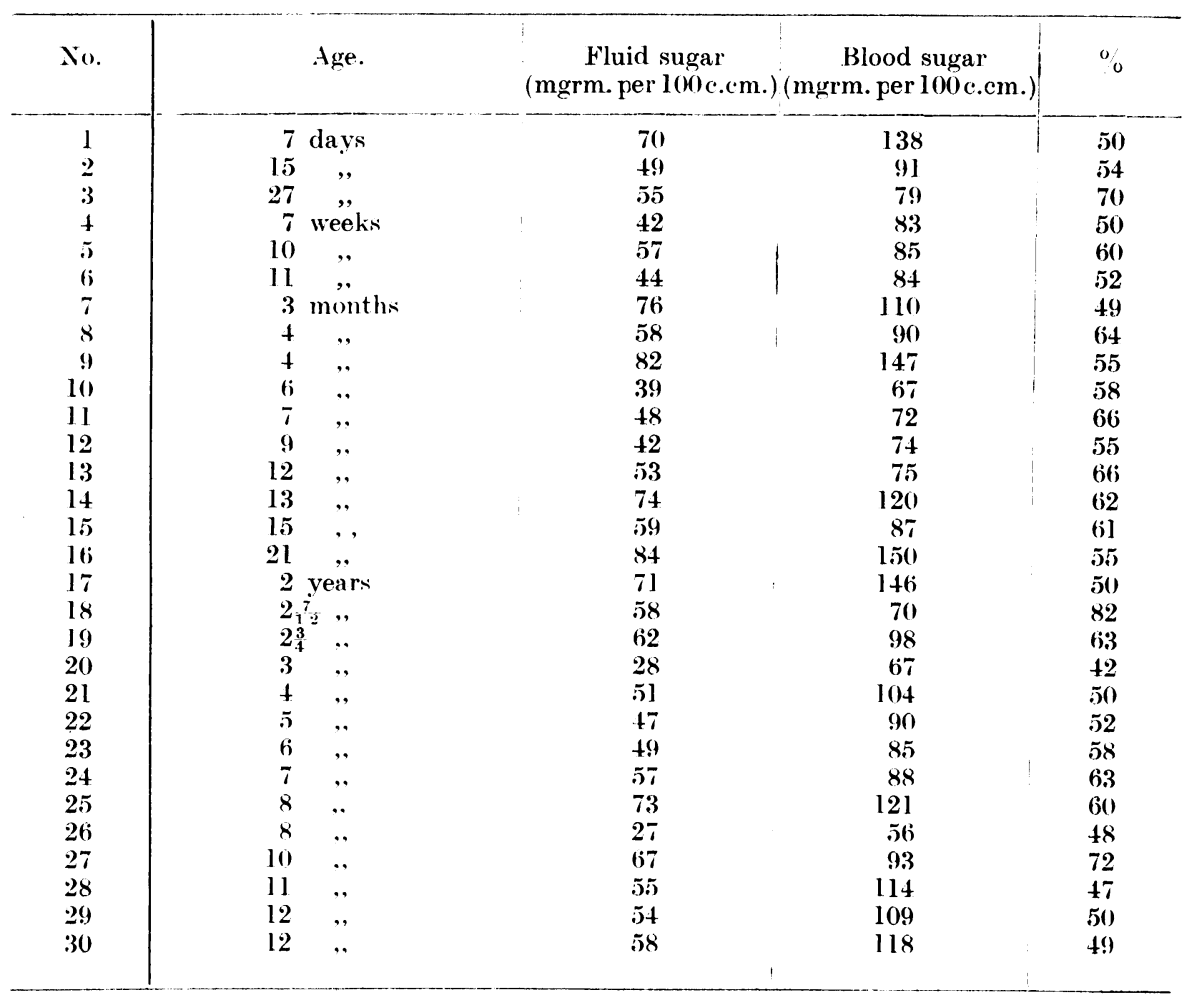


spinal fluid is from 40 to 60 per cent. of the sugar content of the blood. By itself the fluid-sugar estimation is not of much value, but when expressed as a percentage of the blood sugar, it is of definite use to the clinician. Nawratski ${ }^{15}$, Ino $^{16}$, and Kimura ${ }^{17}$ have all shown that in dogs and rabbits the spinal fluid sugar follows the blood-sugar changes after a latent period, and Goodwin and Shelley ${ }^{18}$ have concluded from their work on the subject that the percentage relation between the two is fairly constant at from 45 to 65 per cent.

Table VII shows the sugar content in thirty lumbar fluids of normal infants and children. The fluids were withdrawn, as far as possible, from ' fasting' children. The blood sugar was also estimated in every case. In the last column, the fluid sugar is expressed as a percentage of the blood sugar.

From this table it may be seen that the spinal fluid sugar varied from 42 to 82 per cent. of the blood sugar. In one case it was 82 per cent., in one 72 , and another 70 per cent. The great majority of the cases lay between 45 and 66 per cent. of the blood sugar. It may also be seen that in no case was the fluid sugar more than the blood sugar.

The amount of sugar in the lumbar fluid varied from 27 to $84 \mathrm{mgrms}$. per $100 \mathrm{c.cm}$., the majority of the readings being between 45 and $70 \mathrm{mgrm}$.

The blood sugar varied from 56 to $140 \mathrm{mgrm}$. per $100 \mathrm{c.cm}$.

Graph showing Relationship of Fluid and Blood Sugar.

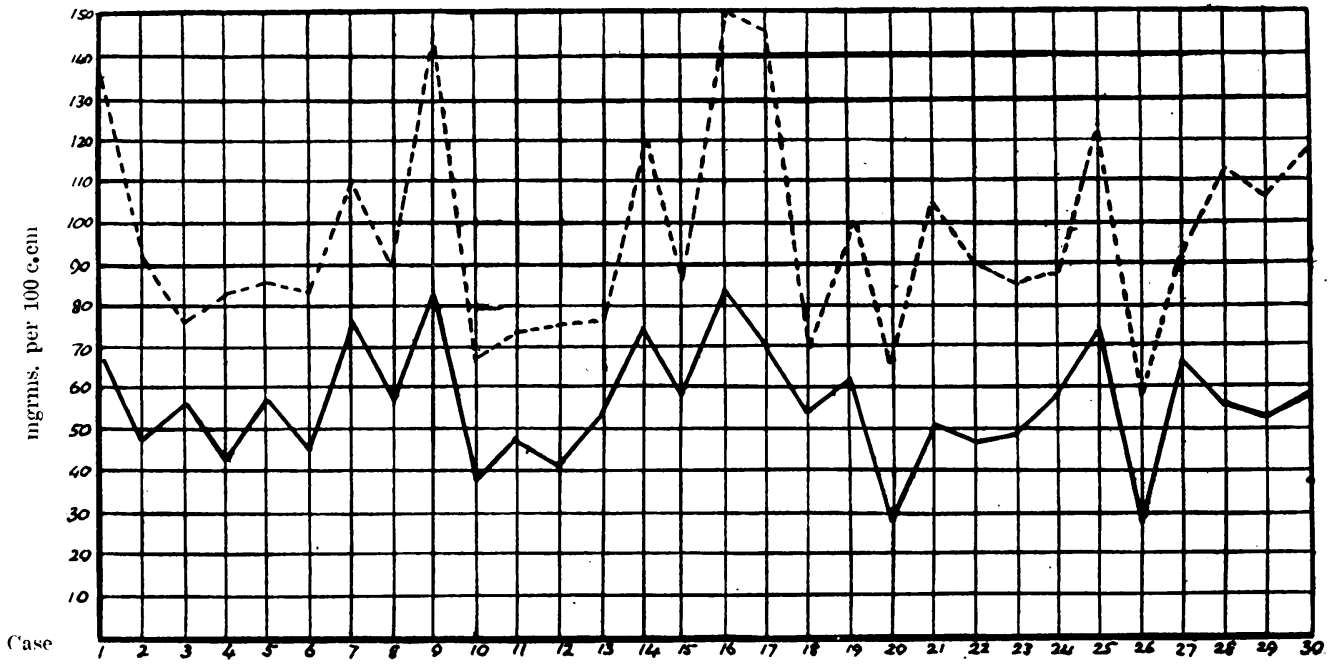

Blood Sugar.

Fluid Sugar.

The sugar content of the cistern fluid was estimated in ten of the cases. In every case the readings were almost identical with those from the lumbar fluid. These are shown in Table VIII, compared with the blood-sugar readings. 
TABLE VIII.

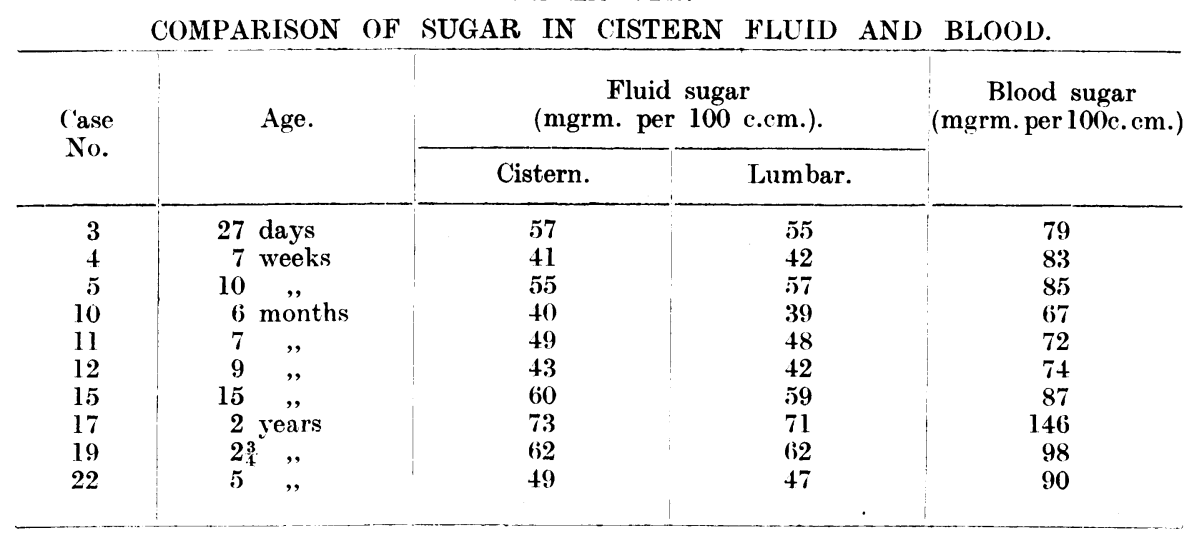

In nine of the cases the sugar content of the ventricular fluid was estimated. In every case it was higher than the content of the lumbar and cistern fluids, but not so high as the blood sugar. This agrees with the observations of Cestan, Riser, and Laborde ${ }^{19}$; and Fremont-Smith and Dailey ${ }^{20}$ in a small series of cases obtained similar results. Table IX shows the readings compared with the lumbar and cistern content, and with the blood sugar.

TABLE IX.

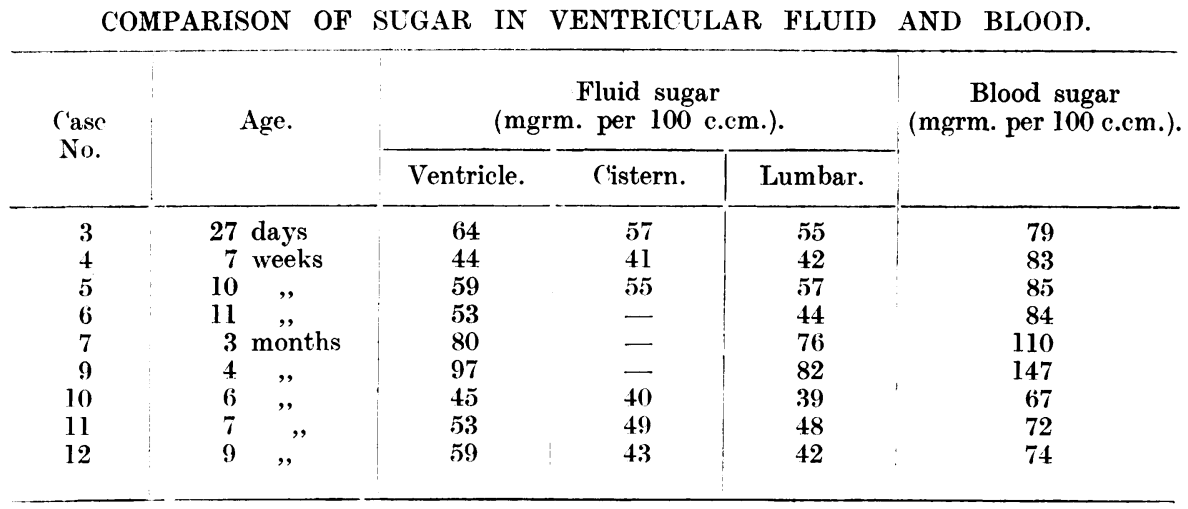

Summary. 1. The lumbar fluid sugar varied from 42 to 82 per cent. of the blood sugar. The great majority of the cases lay between 45 and 66 per cent. of the blood sugar.

2. The amount of sugar in the lumbar fluid varied from 27 to $84 \mathrm{mgrm}$. per $100 \mathrm{c.cm}$.

3. The sugar content of the cistern fluid was practically identical with that of the lumbar fluid in the ten cases investigated, eight cases showing an increase of only from 1 to $2 \mathrm{mgrm}$., the other two cases being equal and $1 \mathrm{mgrm}$. less respectively.

4. In the nine cases examined the sugar content of the ventricular fluid was higher than in the lumbar and cistern fluids, but not so high as in the blood. 
Conclusions. 1. The spinal fluid sugar should always be expressed as a percentage of the blood sugar.

2. In normal children the spinal fluid sugar is 45 to 66 per cent. of the blood sugar.

3. In children the sugar content of the cistern fluid normally is 1 to 2 mgrm. higher than that of the lumbar fluid.

4. The sugar content in the ventricular fluid in infants is considerably higher than in either the cistern or lumbar fluid.

\section{Chloride Content.}

The chloride content of fifty lumbar fluids was estimated. The cistern fluid was examined in thirty-five of these cases, and the ventricular fluid in nine.

Table $\mathrm{X}$ shows the readings from these different loci.

Fremont-Smith and Dailey ${ }^{20}$ state that the normal chloride of the cerebro-spinal fluid in adults varies between 720 and $750 \mathrm{mgrm}$. per $100 \mathrm{c.cm}$. Mestrezat ${ }^{6}$ gives 725 to $\mathbf{7 4 0} \mathrm{mgrm}$., and Eskuchen ${ }^{11}$ finds that the normal variation lies between 725 and 750 mgrm. per $100 \mathrm{c.cm}$.

McLean and McIntosh ${ }^{1}$ state that in infants and young children, the chloride content varies from 600 to $750 \mathrm{mgrm}$. per $100 \mathrm{c.cm}$. of fluid.

Fremont-Smith and Dailey ${ }^{20}$ also found that " an individual, fasting and at rest, will have normally the same chloride content in lumbar, cistern, and ventricular fluid," which is in agreement with the results of Cestan, Riser, and Laborde. ${ }^{10}$

Summary. 1. The chloride content of the lumbar fluids examined varied from 636 to $763 \mathrm{mgrm}$. per $100 \mathrm{c} . \mathrm{cm}$.

2. The chloride content of the cistern and ventricular fluids was practically identical with that of the lumbar fluid.

Conclusions. 1. The chloride content of the cerebro-spinal fluid in children varies from 630 to $760 \mathrm{mgrm}$. per $100 \mathrm{c.cm}$., as compared to the more or less constant level of 720 to $750 \mathrm{mgrm}$. per $100 \mathrm{c.cm}$. in adults.

2. In normal children, the chloride content is the same in lumbar, cistern, and ventricular fluids.

\section{Summary AND Conclusions.}

It may be advisable now to summarize briefly the results obtained in the examination of the fluids.

(1) The pressure studies were only of negative value, but were none the less interesting. They proved the uselessness of manometric readings in young children, where so many disturbing features may be present to upset the calculations. They showed, also, the extreme inaccuracy of estimating the fluid tension by observation of the rate of flow.

(2) The cell count was found to be normally from 20 to 30 per c. $\mathrm{mm}$. in infants, and to decrease gradually as the age increases, becoming identical with that of adults (3-7) at the age of 10 to 12 years.

(3) The total protein content, estimated by the method of Denis and Ayer, was found to approximate in amount to the content in adults. In the lumbar region it varied from 15 to $55 \mathrm{mgrm}$.; in the cisterna magna from 12 to $50 \mathrm{mgrm}$. : and in the lateral ventricles from 5 to $18 \mathrm{mgrm}$. per $100 \mathrm{c}, \mathrm{cm}$, 
TABLE X.

CHLORIDE CONTENT OF CEREBRO-SPINAL FLUID.

\begin{tabular}{|c|c|c|c|c|c|}
\hline \multirow{2}{*}{$\begin{array}{c}\text { Age } \\
\text { group. }\end{array}$} & \multirow{2}{*}{$\begin{array}{l}\text { Case } \\
\text { No. }\end{array}$} & \multirow[b]{2}{*}{ Age. } & \multicolumn{3}{|c|}{ Chlorides (mgrm. per 100 c.cm.). } \\
\hline & & & Lumbar. & Cistern. & Ventricular. \\
\hline 1 & $\begin{array}{r}1 \\
2 \\
3 \\
4 \\
5 \\
6 \\
7 \\
8 \\
9 \\
10\end{array}$ & $\begin{array}{rc}7 & \text { days } \\
15 & ,, \\
27 & , \\
5 & \text { weeks } \\
7 & ,, \\
8 & , \\
10 & , \\
11 & , \\
3 & \text { months } \\
3 & ,\end{array}$ & $\begin{array}{l}670 \\
710 \\
636 \\
705 \\
690 \\
674 \\
663 \\
708 \\
689 \\
716\end{array}$ & $\begin{array}{l}667 \\
\overline{640} \\
- \\
688 \\
- \\
667 \\
713 \\
685 \\
-\end{array}$ & $\begin{array}{l}- \\
\overline{632} \\
\overline{691} \\
\overline{665} \\
705 \\
694 \\
-\end{array}$ \\
\hline II & $\begin{array}{l}11 \\
12 \\
13 \\
14 \\
15 \\
16 \\
17 \\
18 \\
19 \\
20\end{array}$ & $\begin{array}{rc}4 & \text { months } \\
4 & ,, \\
6 & ,, \\
6 & , \\
7 & , \\
9 & , \\
9 & , \\
10 & , \\
12 & , \\
12 & ,\end{array}$ & $\begin{array}{l}723 \\
706 \\
659 \\
742 \\
679 \\
703 \\
732 \\
695 \\
731 \\
727\end{array}$ & $\begin{array}{r}730 \\
711 \\
653 \\
- \\
675 \\
709 \\
- \\
690 \\
738 \\
-\end{array}$ & $\begin{array}{r}\overline{705} \\
657 \\
- \\
668 \\
711 \\
- \\
- \\
-\end{array}$ \\
\hline III & $\begin{array}{l}21 \\
22 \\
23 \\
24 \\
25 \\
26 \\
27 \\
28\end{array}$ & $\begin{array}{l}13 \text { months } \\
15 \quad, \\
15 \quad, \\
18 \quad, \\
19 \text {," } \\
21 \text {,' } \\
2 \text { years } \\
2 \quad,,\end{array}$ & $\begin{array}{l}720 \\
687 \\
694 \\
703 \\
715 \\
693 \\
718 \\
688\end{array}$ & $\begin{array}{r}721 \\
679 \\
690 \\
- \\
719 \\
705 \\
- \\
696\end{array}$ & $\begin{array}{l}- \\
- \\
- \\
- \\
- \\
-\end{array}$ \\
\hline IV & $\begin{array}{l}\mathbf{2 9} \\
\mathbf{3 0} \\
\mathbf{3 1} \\
\mathbf{3 2} \\
\mathbf{3 3}\end{array}$ & $\begin{array}{lc}2_{1}^{2} & \text { years } \\
2_{1}^{7} & , \\
2_{1}^{9} & , \\
3 & , \\
3 & ,\end{array}$ & $\begin{array}{l}735 \\
709 \\
697 \\
730 \\
712\end{array}$ & $\begin{array}{l}740 \\
715 \\
705 \\
-712\end{array}$ & $\begin{array}{l}- \\
- \\
-\end{array}$ \\
\hline $\boldsymbol{V}$ & $\begin{array}{l}\mathbf{3 4} \\
\mathbf{3 5} \\
\mathbf{3 6} \\
\mathbf{3 7} \\
\mathbf{3 8}\end{array}$ & $\begin{array}{l}3 \frac{1}{2} \text { years } \\
3_{1}^{8}, ", \\
4 \text { years } \\
5 \quad, \\
5 \quad,\end{array}$ & $\begin{array}{l}734 \\
699 \\
725 \\
692 \\
718\end{array}$ & $\begin{array}{r}736 \\
710 \\
697 \\
710\end{array}$ & $\begin{array}{l}- \\
- \\
-\end{array}$ \\
\hline VI & $\begin{array}{r}39 \\
40 \\
41 \\
+\quad 42\end{array}$ & $\begin{array}{cc}5 \frac{1}{2} & \text { years } \\
6 & ,, \\
7 & , \\
7 & ,\end{array}$ & $\begin{array}{l}726 \\
735 \\
718 \\
763\end{array}$ & $\begin{array}{l}\overline{735} \\
704 \\
759\end{array}$ & - \\
\hline VII & $\begin{array}{l}43 \\
44 \\
45 \\
46\end{array}$ & $\begin{array}{rc}8 & \text { years } \\
8 & ,, \\
8 & , \\
10 & ,\end{array}$ & $\begin{array}{l}717 \\
739 \\
713 \\
683\end{array}$ & $\begin{array}{l}719 \\
730 \\
- \\
-\end{array}$ & - \\
\hline VIII & $\begin{array}{l}47 \\
48 \\
49 \\
50\end{array}$ & $\begin{array}{l}11 \text { years } \\
11 \frac{1}{2}, \\
12, \\
12,\end{array}$ & $\begin{array}{l}729 \\
740 \\
713 \\
728\end{array}$ & $\begin{array}{l}723 \\
748 \\
728 \\
-\end{array}$ & - \\
\hline
\end{tabular}


(4) The sugar content of the fluid in children varies directly with the blood-sugar. In order to be of most use to the clinician therefore, estimation of the fluid sugar should be accompanied by the estimation of the blood sugar. It was found that this relation of the spinal fluid sugar to the blood sugar in children is similar to that which exists in adults.

(5) The chloride content in children was found to vary normally from 630 to $760 \mathrm{mgrm}$. per $100 \mathrm{c.cm}$., that is a variation of $130 \mathrm{mgrm}$. The adult fluid has a fairly constant chloride content of from 720 to $750 \mathrm{mgrm}$. per $100 \mathrm{c} . \mathrm{cm}$., that is a variation of only $30 \mathrm{mgrm}$.

The chemical and cytological examinations of the fluids were carried out from the Royal College of Physicians' Laboratory, Edinburgh, and to the Curator, Sir Robert Philip, and to the Committee of the Laboratory, I am indebted for permission to work there. To Dr. Charles McNeil, Dr. N. S. Carmichael, and Dr. Lewis Thatcher my thanks are due for permission to use their cases in the Royal Hospital for Sick Children, Edinburgh. To the late Dr. J. W. Dawson, and to Dr. Fergus Hewat and Mr. N. M. Dott, I have also to acknowledge my indebtedness for valuable assistance in many ways.

\section{REFERENCES.}

1. McLean, S., and Mc.Intosh, R., The Human C'erebro-spinal Fluid, N.Y., 1926, 296.

2. Wilcox, H. B., and Lyttle, J. I)., Amer. J. Dis. Child., (hic., 1925, XXX, 513.

3. Levinson, A., The C'erebro-spinal Fluid in Health and Disease, Lond., 1923, 74.

4. Ayer, J. B., The Human Cerebro-spinal Fluid, N.Y., 1926, 159.

5. Fuchs, A., and Rosenthal, R., Weiner Med. Presse., Vienna, 1904, XLV, 2081.

6. Mestrezat, W., Aln. de l'Inst. P'asteur, Paris, 1924, XXXVIII, 719.

7. Ravaut, P., and Boyer, L., Presse med., Paris, 1920, XXVIII, 42.

8. Denis, W., and Ayer, J. B., Arch. Int. Med., Chic., 1920, XXVI, 436.

9. Ayer, J. B., and Foster, H. E., J. Amer. Med. Ass., ('hic., 1921, LXXVII, 365.

10. Greentield, J. G., \& ('armichael, E. A., The C'erebro-spinal Fluid in Clinical Diagnosis, Lond., 1925, 62.

11. Eskuchen, K., Die Lumbalpunlition, Vienna, 1919, 63.

12. Young, G. A., and Bennett, A, E., Amer. J. Ied. Sci., Philad., 1926, CLXXII, 249.

13. Fremont-Smith, F., and Ayer, J. B., The Human ('erebro-spinal Fluid, N.Y., 1926, 100 .

14. Maclean, H., Biochem. J., Camb., 1914, VIII, 391 ; J. Physiol., Lond., 1916, L, 168.

15. Nawratski, E., Ztschr.f. Physiol. Chem., Berlin, 1897, XXIII, 532.

16. Ino. I.. Acta schol. Med., Unic. Imp. Kioto, Tokyo, 1920, III, 40, 609.

17. Kimura, N., Japan Med. World, Tokyo, 1923, III, 67.

18. Goodwin, G, M., and Shelley, H·J., Arch. It. Med., ('hic., 1925, XXXV, $2+2$.

19. C'estan, Riser, and Laborde, Rer. Veurol., Paris, 1923, XXX, 353.

20. Fremont-Smith, I., and Dailey, M. E., The Human Cerebro-spinal Fluid, N.Y., 1926, 111. 